\title{
Analogical viewpoint of fisheries and aquaculture between Bangladesh and Nigeria: potential of knowledge transferability
}

\author{
Ibrahim Shehu Jega $^{1 \& 2}$, Mohammad Mahfujul Haque ${ }^{3}$ and Md. Idris Miah ${ }^{2}$
}

${ }^{1}$ Department of Forestry and Fisheries, Kebbi State University of Science and Technology, Aliero, Nigeria

${ }^{2}$ Department of Fisheries Management, Bangladesh Agricultural University, Mymensingh-2202, Bangladesh

${ }^{3}$ Department of Aquaculture, Bangladesh Agricultural University, Mymensingh-2202, Bangladesh

\begin{tabular}{|c|c|}
\hline ARTICLE INFO OPEN ${ }^{\text {ACCESS }}$ & Abstract \\
\hline $\begin{array}{l}\text { Article history: } \\
\text { Received: 07 June } 2018 \\
\text { Accepted: } 17 \text { November } 2018 \\
\text { Published: } 31 \text { December } 2018\end{array}$ & \multirow{3}{*}{$\begin{array}{l}\text { The inland fisheries and aquaculture of Bangladesh and Nigeria were critically examined with a view to } \\
\text { comparing their fish production and farming systems, nature of seed supply, contribution to country's } \\
\text { Gross Domestic Product (GDP) and the transferability of experiences towards development of the } \\
\text { fisheries sector. A review-based study was conducted based on the available information in journals } \\
\text { articles, reports, Bangladesh and Nigeria Departments of Fisheries Statistical Year Books, text books, } \\
\text { thesis and web documents. There are considerable similarities between Bangladesh and Nigeria in terms } \\
\text { of geographical position, agro-ecology, fisheries resources and the socio-economic condition, fish eating } \\
\text { tradition and domestic demand for fish consumption of the people. Bangladesh aquaculture systems } \\
\text { though mainly semi-intensive but more developed than that of Nigeria in terms of fish seed and feed } \\
\text { supply while Nigeria, though adopts the intensive culture technique but experiences lower production and } \\
\text { higher import of fish. From the findings of this review, it could be argued that Bangladesh needs to fully } \\
\text { harness its abundant resources such as seeds, ponds, water, so as to achieve self-sufficiency in fish supply } \\
\text { and develop export market. Alternatively, Nigeria needs to adopt, diversify and invest more in } \\
\text { aquaculture and fisheries receiving learning from an aquaculture growing country, like Bangladesh, so as } \\
\text { to increase production and reduce import. }\end{array}$} \\
\hline $\begin{array}{l}\text { Keywords: } \\
\text { Bangladesh; Nigeria; Aquaculture; } \\
\text { Inland fisheries; Knowledge } \\
\text { transferability } \\
\end{array}$ & \\
\hline $\begin{array}{l}\text { Correspondence: } \\
\text { Ibrahim Shehu Jega } \\
\text { 凶: ibrahimshehu77@yahoo.com }\end{array}$ & \\
\hline
\end{tabular}

\section{Introduction}

Fisheries and aquaculture make critical contributions to development in the areas of employment, food security and nutrition for the over 41 million people worldwide engaged in fishing and fish farming, the vast majority of whom live in developing countries (Finegold, 2006). According to FAO (2016), the world average per capita consumption of fish stands at $20 \mathrm{~kg}$ per annum. Fish is a vital source of food for people and it is man's most important single source of high-quality protein by providing $\sim 17 \%$ of the animal protein consumed by about one billion of the world's population (FAO 2014). However, in 2010 - 2012, about 870 million people - or one in eighth of the people in the world - did not consume enough food to cover their minimum dietary energy requirement and of these people, 852 million were in developing countries (FAO, 2013a).

Bangladesh and Nigeria are two developing countries in different continents (Asia and Africa), far apart from each other $(8772 \mathrm{~km})$ but resemble in many common attributes. Bangladesh and Nigeria's population as at July 12014 is estimated at 158512570 and 178516904 people and rank 8 and 7, respectively, in the list of countries by population (Worldometers, 2012).

The current world is undergoing the globalization shift which refers to the interchange of world views, products, technologies, ideas and mutual sharing, and other aspects of culture. In this milieu, the role of technology adoption has been recurrently described in the growing economic literature. The developing countries do not adopt new technology equally and per capita income of those countries would not change positively even if the distribution of technology adoption is constant over time Mayer (2000). To reduce the gap between developed and developing countries, developing countries will need to upgrade their level of technology faster than the advanced countries (Mayer, 2013). In agricultural export trade, the developed countries import various food items (e.g. fish) from developing countries that influence the production systems at the producer level in different ways, therefore learning and sharing of advanced knowledge of fisheries and aquaculture among the developing countries is inevitable. As with amongst other developing countries, Bangladesh and Nigeria are undergoing the globalization shift, therefore, technological sharing and upgrading is the unique opportunity to raise per capita income (Mayer, 2000).

In the area of aquaculture, cross-country technological transfer between African and Asian countries has shown positive impacts in various domains. Researchers and experts of different continents worked together to transfer and share aquaculture technologies between Asian and African countries. Under SARNISSA, the 
WorldFish having the Asian experience transferred various aquaculture technologies in Cameroon, Southern Africa and Democratic Republic of Congo. Asian Institute of Technology (AIT) has provided huge information of aquaculture technologies the platform of the project. The information communication technology (email group, website, etc.) based platform developed by SARNISSA created the avenue of sharing technical information, ideas of problem solution, trade of aquaculture equipment, etc (SARNISSA, 2013). Through this platform, African partners have been able to tackle the disease problem of marine shrimp in Mozambique. These all indicate that cross country technology sharing and transfer has a great potential to uphold fish production and national economy. Knowledge transfer and capacity building can cross cultures and political jurisdictions and cooperation can occur between distant ecosystems experiencing common challenges (Liu et al., 2013; Abigail et al., 2016). Though some comparative studies between Bangladesh and Nigeria have been conducted (Islam, 2006; Lola, 2009), they were basically centered on bureaucracy, globalization and poverty. There is dearth of linkage of existing aquaculture practices and knowledge between these two developing countries. Gaining knowledge on such potential as part of doctoral study by a $\mathrm{PhD}$ fellow (first author) from African country in Bangladesh would have multiplier impacts by having broader understanding on existing knowledge base. In this context, reviewing available literature from various sources, this paper attempts to examine the contribution of fisheries and aquaculture sectors, the role played by government, and the potentials of transferability of aquaculture experiences between Bangladesh and Nigeria.

\section{Geographical positions}

By virtue of the geographical location of Bangladesh and Nigeria, they fall in the north latitude of this planet (Fig. 1). The physical geography of Bangladesh is slightly variable characterized by two distinctive features: a broad deltaic plain subject to frequent flooding, and a small hilly region crossed by swiftly flowing rivers. Due to this physiographic feature, about $80 \%$ of the landmass is made up of fertile alluvial lowland. The Tropic of Cancer passes through Bangladesh having a monsoon climate characterized by wide seasonal variations in rainfall, high temperatures, and high humidity. Three distinct seasons are generally recognized: a hot, muggy summer from March to June; a hot, humid and rainy monsoon season from June to November; and a warm-hot, dry winter from December to February. In general, maximum summer temperatures range between 38 and $41^{\circ} \mathrm{C}$. April and January are the hottest and coolest months, respectively, in most parts of the country which receive at least $2,300 \mathrm{~mm}$ of rainfall per year, except for the relatively dry western region of Rajshahi where the annual rainfall is about 1,600 $\mathrm{mm}$.

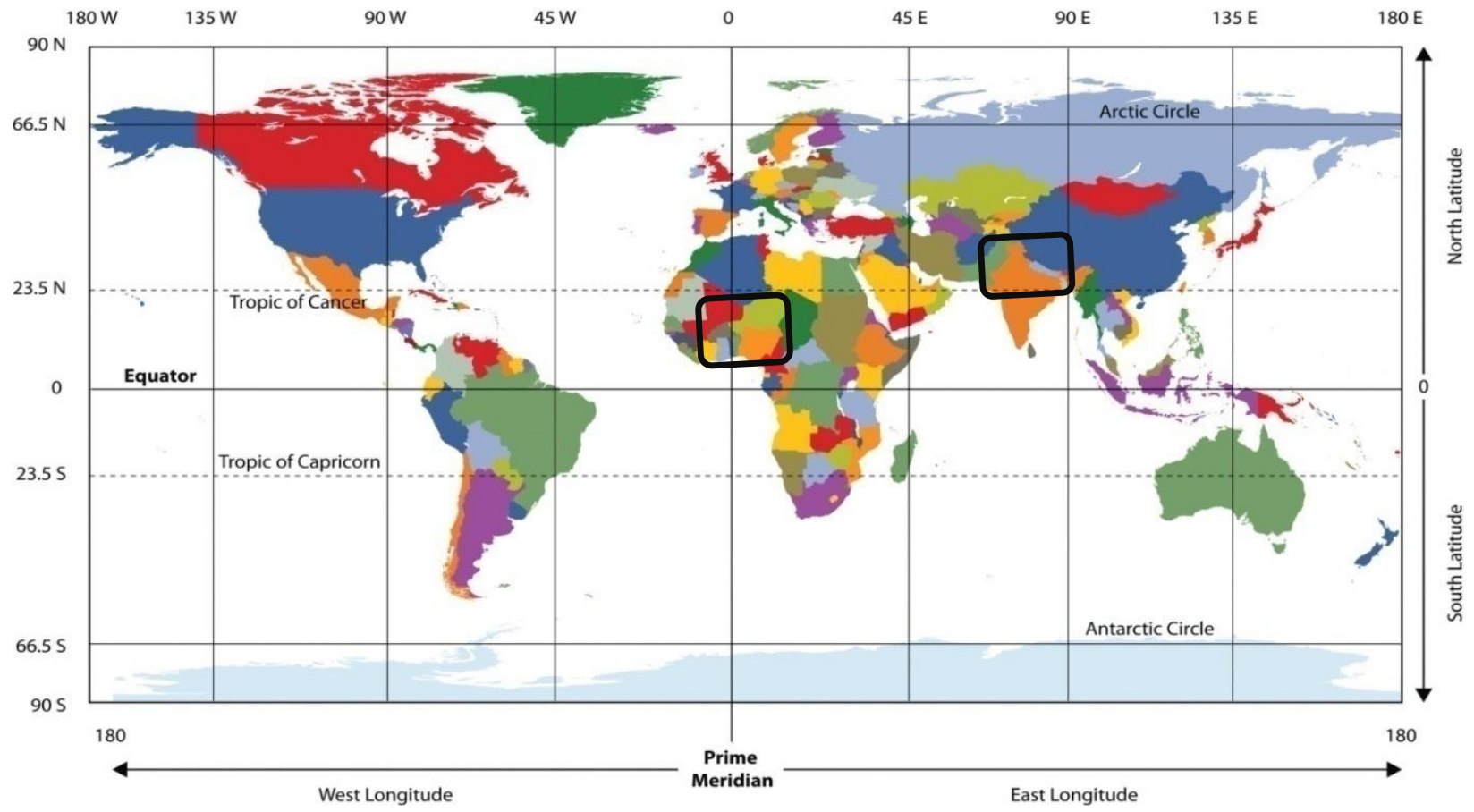

Fig. 1. Geographical Position of Nigeria (encircled left) and Bangladesh (encircled right) in North Latitude of World Map. 
Nigeria locates within the Equator and the Tropic of Cancer. The arid plains in the north give way to savannah in the central hills and plateau, merging into tropical rain forests in the southern lowlands and mountains to the southeast. The tropical climate in Nigeria exhibits a well marked rainy and dry season with a single peak known as the summer maximum due to its distance from the equator. Temperatures are above $18^{\circ} \mathrm{C}$ throughout the year. The central Nigeria has a temperature range of $18.45^{\circ} \mathrm{C}$ to $36.9^{\circ} \mathrm{C}$, and an annual rainfall of about $1,500 \mathrm{~mm}$ with single rainfall maxima in September.

The similarities between Bangladesh and Nigeria in terms of geographical position, tropical weather and soil types to a greater extent indicates the potential of corresponding aquaculture systems adopted. While the earthen ponds predominates in Bangladesh due to the higher water holding capacity of the soil, in Nigeria, the use of earthen ponds is possible in the southern part and along flooded plains and coastal flats.

\section{Inland water resources}

Both countries are endowed with vast inland fisheries and aquaculture potentials and contribute significantly to their continents share of fish production and consumption. Bangladesh is ranked as the $5^{\text {th }}$ largest aquaculture producing country and $4^{\text {th }}$ largest producer for inland fisheries with estimated total production of 1 726066 tons and 957095 tons in 2012 for aquaculture and inland fisheries respectively (FAO, 2014). Both sectors have recorded remarkable increase in production, 1023991 and 2061057MT, for capture and aquaculture, respectively, (DoF, 2015; FAO, 2016). Inland capture fisheries production per unit area of a country (tons $/ \mathrm{km}^{2}$ ) is an indication of the importance of inland fisheries in a country. Bangladesh (4.7 tons $/ \mathrm{km}^{2}$ ) stand out $1^{\text {st }}$ among the 20 countries in inland capture fisheries production per unit area followed by Cambodia $\left(2.0\right.$ tons $\left./ \mathrm{km}^{2}\right)$ and Uganda (0.9 tons $\left./ \mathrm{km}^{2}\right)$ while the remaining 17 range from 0.5 to 0.2 tons $/ \mathrm{km}^{2}$ (FAO 2003a). The ponds constitute the $2^{\text {nd }}$ in terms of water area (377968ha) but account for the highest aquaculture (43.72\%) in Bangladesh. This is followed by the floodplains which constitute the highest amount of inland water area (2692964 ha) with $20.09 \%$ capture fish production (DoF, 2015).

Nigeria is another country in which inland catches have been growing very rapidly in recent years: about 100 000 tons were reported in 1997 while over 354466 tons were reported in 2012, ranked $8^{\text {th }}$, mostly from river Niger and Benue (FAO, 2014; Bartley et al., 2015; FAO, 2016). However, as a result of obnoxious fishing methods such as use of beach seine nets, over fishing and inefficiency of fisheries management policies, the status of the inland waters have deteriorated whereby most of the fishes have suffered depletion and are now in danger of extinction (Chilaka et al., 2014; Jamabo and Hart, 2015). Though the growing aquaculture industry has attempted to fill the gap between demand and supply as the global appetite for fish continues to increase, its capacity might be enhanced by collaboration and cooperation with countries having better track record in fisheries and aquaculture.

Nigeria is blessed with a vast expanse of inland freshwater and brackish ecosystems and the bulk of which constitutes the rivers, lakes, reservoirs and floodplains (capture) while fish ponds constitute only about 5500 ha (Ita, 1993). This clearly demonstrates to the low aquaculture production in Nigeria compared to Bangladesh. Nigeria was not listed among the 20 countries with annual production of 200535 tons despite the immense quantity of freshwater. Some of the constraints leading to low productivity include inadequate supply of input and lack of capital to artisanal fishermen, the changing nature of the seasonal streams/rivers as a result of climate change, and poor management of the rivers by the authorities. Moreover, the promotion of pond based aquaculture was not strengthened scientifically by the government and developers, which has got tremendous attention in Bangladesh as with many other developing countries in Asia.

Due to the declining trend of open water fisheries production, cage culture is being promoted in different parts of Bangladesh. Cage culture was experimented with poor households in 80s and 90s to improve the level of protein rich food consumption however in last decade; it has been commercialized by the large entrepreneurs in rivers in southern Bangladesh (Sarker, 2009). Cage culture enterprises created various segments in its upstream and downstream value-chain in terms of local and international trading of cage materials, seed production and supply chain, feed production and supply networks, drugs and chemical supply and fish marketing which further created huge employment opportunities in the rural and peri-urban areas of Bangladesh (Sarker, 2009). A recent study has supplemented some technical values to cage to produce fish and vegetables in an integrated system which is acronymed as IFCAS (Integrated Fish Cage Aquageoponics System) technology (Haque et al., 2015). Nigeria, with relatively less fish ponds, may increase fish production through the utilization of her vast inland water resources for cage culture especially for the vast majority of the rural fisher folks in the north where there is low rainfall and construction cost of concrete tank is very high. In the same vein, for areas in the riverine and southern part, with vast water bodies, most of the inhabitants are relatively poor. There is therefore the need to utilize available waters effectively for food fish production without necessarily exerting more demands on land use for such purposes. Cage fish farming may be encouraged as an alternative livelihoods and income generation avenue which may result in high returns relatively quickly compared to other agricultural investments in Nigeria. In addition to that cage aquaculture enterprises can generate employment opportunities for the people of poor neighboring countries of Nigeria that is evident in Thailand where many migrants from Myanmar working in aquaculture farms (ILO, 2015). 


\section{Fisheries Sector}

Fisheries play an important role in Bangladesh national economy which account for $4.7 \%$ of GDP, $9.1 \%$ of the export earnings and $6 \%$ of the supply of protein (DoF, 2015). Aquaculture is perceived as an embedded part of fisheries in Bangladesh. The capture fisheries are declining due to various anthropogenic and environmental causes. The fisheries sector as a whole including aquaculture is being promoted by the considerable government and foreign investments to improve fish production, nutrition and income and employment generation of poor and marginal people.

Based on the GDP per capita of the two countries (Table 1), Nigeria appears to be richer than Bangladesh, though their population is slightly different. The Nigerian food basket reflects the diverse culture of more than 500 different tribes and languages that reside in Nigeria (The Nigerian Foods, 2016). However, as with other developing countries the people of Nigeria are suffering from malnutrition, particularly protein rich foods, with $29 \%$ of Nigerian children reported to be underweight (NDHS, 2013). As a source of animal protein, fish and fish products locally provide nearly per capita consumption of $13.9 \mathrm{~kg}$ of fish per capita per annum as compared to recommended rate of $21 \mathrm{~kg}$ per capita per year (Belton and Thilsted, 2014); an equivalent of $40 \%$ of all animal protein consumed in the country while the contribution of the fisheries sub-sector to national development include such activities as employment generation, income generation and household food security (Sikoki, 2013).

Table 1. Comparison of the Fisheries Sector of Bangladesh and Nigeria

\begin{tabular}{lccc}
\hline \multicolumn{1}{c}{ Particulars } & Bangladesh & Nigeria & Source \\
\hline Area (sq.km) & 147570 & 923768 & Shimang (2005) \\
Water area (sq.km) & 45757 & 286200 & DoF (2015);Ita (1993) \\
Inland water bodies (reservoirs, lakes, rivers, ponds) (ha) & 4708193 & 19958100 & Rahman and Akhter (2015); \\
Brackish waters (ha) & 3169800 & 741509 & Sikoki (2013) \\
Length of continental coastline (km) & 714 & 853 & \\
Exclusive Economic Zone (sq.km) & 166000 & 25900 & Worldometers (2012) \\
Population (million) & 158512570 & 178516904 & NBSN (2015) \\
Per capita GDP (US \$ billion) & 1096.6 & 3184.6 & \\
Agriculture GDP (US \$ billion) & 67467 & 17514.10 & Banglapedia (2009) \\
Fisheries GDP (US\$ billion) & $10042(4.7 \%)$ & $210.17(1.2 \%)$ & FAO (2013b) \\
Population of fisher people (million) & 5.2 & 2.0 & Belton and Thilsted (2014)) \\
Fish consumption per capita (kg) & 18.7. & 13.9 & FAO (2010) \\
Fish contribution to total animal protein intake (\%) & 56.2 & 43.1 & FAO (2013b) \\
Government cash expenditures on agriculture, forestry, & 8.9 & 0.9 & FAO (2013b) \\
fishing and hunting 2009-2011(million US\$) & 0.2 & 0.0 & The Fishsite (2014) \\
Fishery share of official development assistance (2010) (\%) & 3950 & 500000 & Fish import (tons) \\
\hline
\end{tabular}

Despite that, the government of Bangladesh is committing more funds to the agricultural sector, including fisheries and aquaculture and more people are engaged in fisheries and aquaculture. Aquaculture production has become more international either through foreign direct investment (directly by setting up aquaculture installations or through the purchase of existing companies) or through subcontracting parts of the aquaculture process to other companies (OECD, 2010). For effective development of aquaculture and fisheries in Nigeria, there is need for more government investment and infrastructural improvement in such areas as power supply to support not only residential but also commercial farming.

\section{Aquaculture systems}

In Bangladesh, aquaculture production systems have become mainly semi - intensive and in few cases intensive systems (FRSS, 2015), depending on the level of management inputs, especially in stocking and feeding. Indian major carps, some exotic Carps and catfishes are the main aquaculture species in Bangladesh (Table 2). In Nigeria, with most of the cultured fish produced from commercial farms, the intensive culture system is more common with fertilizers and pellet feeds applied, however, extensive and semi-intensive culture systems can be practiced within wetland ecosystems which can provide a consistent food supply for both partly marine and mainly for freshwater species (Bolorundoro, 1999; Miller et al., 2006; Dauda, 2014). The major aquaculture species in Nigeria are catfish and tilapia (Table 3).

Table 2. List of Cultured Fish Species in Bangladesh

\begin{tabular}{ll}
\hline Common name & Scientific name \\
\hline Catla & Gibelion catla \\
Rui & Labeo rohita \\
Mrigal & Cirrihinus cirrhonus \\
Kalbaush & Labeo calbasu \\
Silver carp & Hypophthaimicthys molitrix \\
Common carp & Cyprinus carpio \\
Grass carp & Ctenopharyngodon idella \\
Bighead carp & Aristichthys nobili \\
Silver barb & Barbades gonionotus \\
Thai pangas & Pangasius sutchi \\
Nile tilapia & Oreochromis niloticus \\
Ilsha bata & Labeo bata \\
Kurio labeo & Labeo gonia \\
Walking catfish & Clarias batrachus \\
Stinging catfish & Heteropneustes fossilis \\
\hline
\end{tabular}

Source: FRSS (2014) 
Table 3. Commonly cultured fish species freshwater fish ponds in Nigeria

\begin{tabular}{ll}
\hline Common name & Scientific name \\
\hline Tilapia & Oreochromis niloticus \\
& Tilapia guinensis \\
& T. melanopleura \\
& Sarotherodon galilaeus \\
Mud catfish & Clarias gariepinus \\
Spotted catfish & Synodontis filamentosus \\
Red mud catfish & Heterobranchus bidorsalis \\
Grey catfish & Chrysichthys nigrodigitatus \\
Catfish & Citharinus citerus \\
Nile perch & Lates niloticus \\
African bony tongue & Heterotis niloticus \\
Common carp & Cyprinus carpio \\
African carp & Bagrus bayad \\
Indian carps & Catla catla \\
& Labeo rohita \\
Moon fish & Cirrhinus mirgala \\
Trunk fish & Labeo coubie \\
\hline
\end{tabular}

Source: Ita (1989)

\section{Pond aquaculture}

Fish is produced in a variety of production systems in Bangladesh but ponds are by far the most important (Haque et al., 2015), mainly as a result of advanced aquaculture technologies and markets, availability of fish seed, fish feed and other necessary production inputs.

Fish pond aquaculture production in Nigeria is currently very low, estimated at below 10,000 MT/year from a total water surface area of about 5,500 hectares (Miller et al., 2006). Fish production technique adopted varies according to agro-ecological zones. Fish pond system is the commonest technique in the Niger Delta Region of Nigeria. Earthen ponds are preferred in this region (Southern Nigeria) because of cheap source of underground water from inundated swamps and clay soil that retains water. Fish farming is majorly carried out in outdoor or indoor concrete or plastic tanks in other parts of Nigeria. According to Adeogun et al. (2014), 58.3\% of fish farmers used concrete tanks in rearing fish, $16.5 \%$ used earthen (Dug-out) ponds, 23.3\% plastic while $2.8 \%$ used fibre - glass tanks. Other types of rearing facilities include wooden tanks, collapsible tarpaulin tanks, etc. Production tanks vary in sizes and shapes, however, round tanks between 5000 to 10000 litres are most commonly used (Mirzoyan et al., 2010). One of the constraints to the development of pond aquaculture in Nigeria is the lack of enthusiasm to adopt aquaculture technologies due to poor aquaculture extension services, despite the comparative advantage of earthen ponds over concrete tanks in terms of cost, production and income (Egware and Erewa, 2014). Nigerian investors are mostly interested in quick business for protein supply rather than in developing a technology (Miller et al., 2006). Pond based aquaculture in Bangladesh created double opportunities for fish and horticulture production, which can be replicated with
Nigerian poor where applicable. For instance integration of fish production with grain and vegetable farming will supplement the income from fish farming and by producing grain, vegetables, fruits and fish, the community becomes self-sufficient with regards to food. The dominance of pond aquaculture production in Bangladesh may be attributed to its agro-ecological disposition. Due to the increasing size of population thereby increasing buying and leasing value of land/pond, pond aquaculture would be inaccessible for poor and marginal people in Bangladesh. Therefore, tank based aquaculture being practiced by Nigerian people using plastic, wooden and collapsible tanks may be adopted by the resource poor farmers both in rural and urban areas of Bangladesh.

\section{Cage culture}

Cage culture started in Bangladesh since 80s, however, in the last decade it has got commercial entrepreneurial shape particularly in the slow flowing rivers in southern Bangladesh. Cages are used as a form of farming in their own right within flowing or large bodies of water and can also be used in small pond fish culture to protect fingerlings in the initial stages of development (Bot et al., 2011).

Nigeria is not recognized as one of the prominent cage culture practicing countries (FAO, 2007a). Main constraints to the development of competitive cage culture in Nigeria and Africa as a whole include the unavailability of locally produced, high quality extruded feeds at competitive prices using local raw materials. Other constraints include a lack of training in cage culture, a lack of processing and routes to developed markets in some countries, traditionally low prices and quality of wild caught fish in the region, lack of potential investors willing to take a long- term investment risk in Nigeria and lack of expertise in disease identification and management (Blow and Leonard, 2007).

However, considering the availability of vast rivers, lakes and reservoirs, adoption of cage culture, along with partnership of Nigeria with Bangladesh, may serve as panacea for the slow growth of aquaculture in Nigeria. This entails bilateral cooperation between the two governments to facilitate interaction and brainstorming between agencies, aquaculturists and fisheries managers, other academicians and international organizations.

\section{Aquaculture practices}

Fish feeding: The growth of commercial aquaculture and commercial feed production in the last ten years in Bangladesh has been extremely increasing. With the intensification and commercialization of aquaculture, commercial pellet feeds have substantially replaced home-made and raw unformulated feeds (Apu, 2014). Most of the fish feed for commercial aquaculture in 
Bangladesh is produced within the country using fish and fishery by products (tail, bones, visceral). This makes fish feed easily accessible and somewhat affordable. Low-cost pellet feed production machine was manufactured locally and being used by fish farmers. It also created enterprise and employment for the farmers.

Fish feed technology is one of the least developed sectors in Africa (Gabriel et al., 2007). Fish farmers depend largely on imported fish feed from Europe thereby increasing the total cost of production (AIFP, 2004). Nigeria is blessed with abundant shrimp from the coastal region. Its utilization along with other source for feed manufacture within the country may cushion the cost of feed usually imported into the country. Low cost feed production device technology can be disseminated in Nigeria where applicable, i.e. aquaculture is not simply a technology to produce food fish but to produce multiple value chain segments for employment generation.

\section{Breeding (Seed production)}

Aquaculture practices in Bangladesh started with seed collected from rivers, but now it is almost entirely $(99.55 \%)$ replaced by hatchery-produced seed (FRSS, 2013). The main sources of fish fry in Bangladesh are produced in government and private hatcheries, and some collected from rivers. At present the total number of fish hatcheries are 936 of which government fish farms are 77, other government hatcheries 7 and private fish hatcheries are 852 (DoF, 2013). In the year 2013, the total fry production from hatcheries in Bangladesh was $487453 \mathrm{~kg}$ of which $9890 \mathrm{~kg}$ was from public hatcheries and $477563 \mathrm{~kg}$ was from private hatcheries (Table 4).

Table 4. Production of hatchlings in Government and Private sector hatcheries in Bangladesh in 2013

\begin{tabular}{lccc}
\hline Source & $\begin{array}{c}\text { Number of } \\
\text { hatcheries }\end{array}$ & Percentage & $\begin{array}{c}\text { Quantity of } \\
\text { hatchling } \\
\text { produced (kg) }\end{array}$ \\
\hline $\begin{array}{l}\text { Government } \\
\text { hatcheries }\end{array}$ & 84 & 8.97 & 9890 \\
$\begin{array}{l}\text { Private hatcheries } \\
\text { Total }\end{array}$ & 852 & 91.03 & 477563 \\
\hline
\end{tabular}

Source: FRSS (2013)

The seed industry in Nigeria may be classified for convenience into small-scale, medium and large scale producers. The small-scale producers are those who produce more than 20000 fingerlings during a production season; medium-scale producers usually produce and sell more than 20000 fingerlings during a production season. They account for $60 \%$ of all the fish seed supply in the country, numbering 200 , situated in the south-south and south-west zone; large-scale producers: they produce and supply to the market in excess of 100000 seeds every season and though few in number (about 30), cumulatively supply about $20 \%$ of all the fingerlings available in the market (Atanda, 2007).

More than $80 \%$ of cultured fish in Nigeria is catfish, mainly Clarias spp, Heterebronchus spp and their hybrids followed by the tilapias (Table 4). Unfortunately, however, the required quantity and quality of fish seed have never been available. Total production and supply from all these sources amounts to 55 million fingerlings (Table 5), which is far less than the requirement of about 500 million per annum to satisfy the immediate market need (Atanda, 2007).

Table 5. Freshwater Fish Seed Supply in Nigeria

\begin{tabular}{|c|c|c|}
\hline Source & Percentage & $\begin{array}{c}\text { Seed production } \\
\text { (million) }\end{array}$ \\
\hline $\begin{array}{l}\text { Private sector (ponds, } \\
\text { hatcheries) }\end{array}$ & 80 & 44 \\
\hline $\begin{array}{l}\text { Public sector (government } \\
\text { fish farms, hatcheries, } \\
\text { universities, research } \\
\text { institutions) }\end{array}$ & 10 & 5.5 \\
\hline Wild collection & 9 & 4.55 \\
\hline $\begin{array}{l}\text { Importation and other } \\
\text { sources }\end{array}$ & 1 & 0.55 \\
\hline Total & 100 & 54.60 \\
\hline
\end{tabular}

Source: Atanda (2007)

Progress made in increased aquaculture production in Bangladesh over the last decade, may not be unconnected to the tremendous success achieved in hatchery production of several fish species such as Labeo rohita, Gibelion catla, Cirrhinus cirrhosus, Clarias batrachus, Ompak pabda, etc. There exist over 230 indigenous fish species recorded in Nigerian inland waterbodies (Ita, 1993) which resulting indiscriminate fishing and lack of management strategies, are gradually becoming endangered such as Protopterus annectens, Heterotis niloticus, Oreochromis niloticus, etc. Seed production of these culturable endemic species may enhance the aquaculture production in Nigeria. The government could also facilitate the conservation of these valuable species through technological development by research and general management.

\section{Shrimp farming}

The shrimp production unit in Bangladesh is locally called "gher" farming, which is combined form of aquaculture and agriculture. This industry diversified the shrimp value-chain with various upstream and downstream segments having very high economic importance of domestic and international seafood trade (DoF, 2015).

Nigeria is a maritime state with a coastline of approximately $853 \mathrm{~km}$. Use of beach seines drastically reduces the shrimp abundance because the net lands everything that is swept by the ground rope. This hampers recruitment, thus, shrimp farming is a robust option to improve production as shrimp is the most 
important agricultural export of Nigeria worth US\$ 49 million (FAO, 2007b).

\section{Basic legislation and institutional setup}

In Bangladesh, the basic act regulating inland fisheries is the Protection and Conservation of Fish Rules (1983) and the Marine Fisheries Rules (1983). Other legislations include the Tanks Improvement Act (1939), the Shrimp Culture Users Tax Ordinance (1992) and Bangladesh Fisheries Development Cooperation Act (1973). Nigeria has no specific legislation on aquaculture at national level, nor is this activity mentioned in the decree and regulation of marine sector. However, the Inland Fisheries Decree (1992) empowered the Minister in charge of fisheries matters to determine whether the set up of enclosures such as pens and cages, should be subject to a license fee (FAO, 2005-2015). However, while Bangladesh have developed a highly pluralistic fisheries and aquaculture extension service system as they include a host of organizations and international entities up to the grassroot level carrying out diverse projects along with international Non-Governmental Organizations (NGOs) and farmer associations (GFRAS, 2016), in Nigeria, the real field extension work is carried by Fisheries Superintendents and Fisheries Assistants with limited contact with the fishermen. Their work is limited to obtaining catch statistics of the fishers but not for aquaculture extension (FAO, 1993).

The institutional setup of both countries is quite similar, but the diversity of extension services with particular focus on aquaculture extension has to be improved. In this regard, a closer collaboration between the countries for sharing and learning various aspects of fisheries and aquaculture may be built through the supports of donor agencies.

\section{Fish import and export}

Experts said Bangladesh is almost self-reliant in fish production and consumption as it now produces 3.2 million tons annually against its annual demand of 3.5 million tons (Dhaka Tribune, 2013). The per capita demand and supply gap of fish in Bangladesh is very poor. While demand was estimated as 37.92 million MT per year, the fish supply was 34.10 million MT (DoF, 2015).

Nwafili and Tianxiang (2007) reported that out of the estimated 120 million people in Nigeria in 2000, about $1 \%$ of them engage in fishing and over 24 million depend on fisheries for their livelihoods yet Nigeria imports over 600000 tons of fish annually.

Despite the tremendous progress made in aquaculture development in Bangladesh, more than $40 \%$ of fish supply comes from capture fisheries. Nigeria may drastically reduce fish import by producing more fish internally through proper fisheries management and adoption of improved cage culture techniques. Bangladesh and Nigeria have expressed mutual interest to expand the bilateral trade and investment. The existing bilateral relation between the two countries could facilitate smooth transfer of technological advancement between the two countries. Nigeria has urged Bangladeshi businessmen to invest in Agriculture, food processing, pharmaceuticals, Information and Communication Technology (ICT) and the educational sector (FE, 2012). Transferring aquaculture technology from Bangladesh to Nigeria might open-up other avenues for investment between the two countries such as in the booming garment industry (Bangladesh) and the ailing textile industry in Nigeria.

Fisheries and aquaculture has emerged as the second largest export industry of Bangladesh (Ghose, 2014). Of the total fish production of the country, approximately $97 \%$ is marketed internally for domestic consumption while the remaining $3 \%$ is exported (EPB, 2013). The shrimp industry in Bangladesh accounts for $66.5 \%$ of annual fish exports in terms of volume and $84.6 \%$ in value in 2010 (BBS, 2010). Shrimp exports reached a peak of 53361MT in 2006 but recent figures in 2010 showed shrimp exports totaling 51599MT (BBS, 2010). Nigeria exported USD 83,824 of fishery commodities in 2011 but increased to USD 323,881 in 2012. With a production capacity of $12,000 \mathrm{MT}$ annually, Nigeria's shrimps are at present entirely wild caught from the Niger Delta. The production of young prawn species under controlled condition was attempted in Nigeria without success. As with Bangladesh, Nigeria has the potential of promoting shrimp farming by establishing shrimp hatcheries and farms taking the initiatives of research and development that might further increase the volume of shrimp export. Smoked fish of Clarias, Oreochromis spp and Heterotis spp., largely from Calabar and Lake Chad, are exported to the United Kingdom by airfreight (FAO, 2003b). Nigeria currently exports approximately $5 \mathrm{MT}$ of smoked fish per month. In Bangladesh smoked fish is recent addition to the fishery products (Latifa et al., 2014), however, Bangladesh could diversify her sources of foreign currency by giving more emphasis on smoked fish processing and export.

\section{Aquaculture and social development}

Considering the fact that gender norms and relations constitute the most important socio-cultural constraints on individual's ability to pursue aquaculture efficiently (AFSPAN, 2014), Bangladesh government, NonGovernmental Organisations (NGOs) and donor agencies took aquaculture as an important driver for gender and social development. Agencies like International Fund for Agricultural Development (IFAD), United Nations Development Programme (UNDP), Islamic Development Bank (IDB), are working to improve women's status by including them in the projects main activity of pond aquaculture and by 
supporting them in other income-generating activities (Boto et al., 2013).

In Nigeria, with the exception of catfish, aquaculture has been slow to develop because of low social acceptance despite huge unmet demand for fish because of inappropriate technology, limited value chain development and a focus on household nutrition rather than income generation (AFSPAN, 2014). Although women are actively involved in various sectors of agriculture and fisheries, government has not shown sufficient concern to improve their contribution. However, IFAD, Economic Community of West African States (ECOWAS) Fund and UNDP together assist with gender sensitive components in projects for aquaculture and fisheries development. Such kind of bilateral programme between Asia and Africa needs to be initiated to exchange and share of learning between the regions for broader social development centering aquaculture.

\section{Conclusion}

The transferability of technological knowledge in the field of fisheries and aquaculture between Bangladesh and Nigeria is an important issue of research and development. Unlike Nigeria where laterite soils predominate, presence of alluvial soils across Bangladesh permits diverse use of ponds for aquaculture. However, due the high population density, other non-conventional aquaculture systems - plastic, wooden and collapsible tanks might be ideal for the land-locked and resource poor Bangladesh farmers. Emphasis on smoked fish processing and export could also diversify the country's foreign revenue. Availability of vast rivers and lakes in Nigeria suggest the adoption of cage culture for increased fish production. Nigeria needs to broaden her fisheries and aquaculture system and encourage international participation at the grassroots level. The political will of the two governments is critical for a fruitful and sustainable knowledge transfer. Nigerian government need to invest more towards aquaculture development. Partnership in the aspect of personnel, training and inter-agency cooperation between Bangladesh and Nigeria is necessary for sharing of research experiences. Most significantly, the substantial progress made in Bangladesh in the hatchery production of some indigenous fish species, if similar trend is followed in Nigeria, diversifying the number of fish cultured through domestication, breeding and culture of wild species, may greatly boost fish production and reduce imports. Though proper adoption of new aquaculture technologies - feed, seed, etc, may require increased capital outlay by the Nigerian government, this might be the ideal option for such a mono economic country seeking for diversification. Incorporation of social, cultural and economic development aspects of fishermen need to be adequately considered in future fisheries development plans in Nigeria.

\section{Acknowledgement}

The author is thankful to Prof. Dr. Mohammad Mahfujul Haque, Department of Aquaculture, Bangladesh Agricultural University, Mymensingh, for initiating and supervising this write up. The author is also thankful to the Nigeria Tertiary Education Training Fund, TETFUND 2013/2014 AST\&D Intervention and management of Kebbi State University of Science and Technology, Aliero, Nigeria for providing financial support.

\section{Conflict of interest}

The authors wish to declare that there is no conflict of interest with any person or organization.

\section{References}

Abigail, J.L., Steven, J.C., Andrew, M.D., Shannon, D.B., David, B.B., Ian, G. C., Vivian, M.N., Joel, N., Kaviphone, P., Betsy, R., Mark, W.R., Willian, W.T., Whitney, W., SoJung, Y. and Douglas, B.J. 2016. The social, economic and environmental importance of inland fish and fisheries. Environmental Reviews, 24 (2): 115-121.

Adeogun, O.A., Alimi, T. and Adeyemo, R. 2014. Comparative analysis of profitability and technical efficiency of fish farming using different rearing techniques in Nigeria. Asian Journal of Agricultural Extension, Economics and Sociology, 3(5): 405-418.

AFSPAN. 2014. Identification of enabling and disenabling social and cultural factors affecting aquaculture developmentsynthesis report, Seventh Framework Programme, afspan.eu/publications/reports/afspan. pp 27.

AIFP. 2004. Inventory of feed producers in Nigeria. Aquaculture and Inland Fisheries Project. pp 1-8.

Apu, N. A. 2014. Bangladesh small and medium-scale aquaculture value chain development: Past trends, current status and likely future directions. Nairobi, Kenya: ILRI, 107p.

Atanda, A. N. 2007. Freshwater fish seed resources in Nigeria. In: M.G. Bondad-Reantaso (ed.). Assessment of freshwater fish seed resources for sustainable aquaculture. FAO Fisheries, Technical Paper, No. 501. Rome, 628pp.

Banglapedia, 2009. National Encyclopedia of Bangladesh, Fisheries Resources, National Weekly Fisheries, 2009. Fisheries Study and Pilot projects, Interim Report, Dhaka, 27pp.

Bartley, D.M., De Graaf, G. J., Valbo-orgensen, J. and Marmulla, G. 2015. Inland capture fisheries: status and data issues, Fisheries Management and Ecology, 22:71-77.

BBS. 2010. Bangladesh Bureau of Statistics. Statistical Yearbook of Bangladesh, $23^{\text {rd }}$ Edition. Planning Division, Ministry of Planning, Bangladesh, 744pp.

Belton, B.S. and Thilsted, S. H. 2014. Fisheries in transition: Food and nutrition security implications for the global South. ELSEVIER Global Food Security 3(1):59-66, doi: 10.1016/j.gfs.2013.10.001.

Blow, P. and Leonard, S. 2007. A review of cage aquaculture: subSaharan Africa. In: M. Halwart, D. Soto and J.R. Arthur (Eds). Cage aquaculture - Regional reviews and global overview, FAO Fisheries Technical Paper, No. 498, Rome, $188-207 \mathrm{p}$.

Bolorunduro, I. 1999. Fish culture in ponds. National Agricultural Extension and Research Liaison Services, Extension Bulletin, No. 1003, Fisheries Series. No. 4, 19p.

Bot, C., Graffman, L. and Beckman, C. 2011. Small-scale fish farming in Bangladesh, APPROPEDIA. 7pp.

Boto, I., Phillips, S. and D'Andrea, M. 2013. Fish-farming: the new driver of the blue economy. Brussels Rural Development Briefings, 21pp.

Chilaka, Q.M., Nwabueze, G.O. and Odili, Q.E. 2014. Challenges of inland artisanal fish production in Nigeria. Journal of Agricultural Extension, 17: 123-124. 
Dauda, A.A. 2014. Salvaging Wetland Ecosystem in Nigeria: Towards Ensuring Sustainable Fish Production. Nature and Science, 12(9): 61-67.

Dhaka Tribune 2013. Experts for ensuring quality fish seeds to enhance production. Tribune Business Desk. Published $1^{\text {st }}$ August 2013

DoF. 2013. National Fish Week Compendium 2013. Department of Fisheries, Ministry of Fisheries and Livestock. Dhaka, Bangladesh, 144pp.

DoF. 2015. Fish Week Book. Department of Fisheries (DoF). Ministry of Fisheries and Livestock, Dhaka. Bangladesh, 144pp.

Egware, R.A. and Erewa, S.I. 2014. A comparative profit analysis of catfish (Clarias gariepinus) production in Ugheli, Delta State, Nigeria. Custos e@gronecoceo online 10(1) www.custosonlineagonococeoonline.com.br. Accessed 10 May 2016.

EPB. 2013. Export Promotion Bureau. Annual Report 2011. Dhaka, Bangladesh.

FAO. 1993. Inland fishery resources of Nigeria. CIFA Occasional Paper, No 20. Rome, 120p.

FAO. 1997. Review of the State of World Aquaculture. FAO Fisheries Circular No. 886. Rev. 1. Rome, Italy [PubMed].

FAO. 2000. The State of World Fisheries and Aquaculture. Fisheries resources: trends in production, utilization and trade overview. Rome. $64 \mathrm{pp}$.

FAO. 2003a. Review of the state of world fishery resources: inland fisheries. FAO Fisheries Circular. No. 942, Rome. 60pp.

FAO. 2003b. A study of the trade in smoked-dried fish from W/Africa to the United Kingdom. FAO Fisheries Circular, No. 981, Rome, $17 \mathrm{pp}$

FAO. 2005-2015. National Aquaculture Legislation Overview. Nigeria Fact Sheets. In: D' Andrea A. (Ed.), FAO Fisheries and Aquaculture Department (online). http://www.fao.org/ fishery/legalframework/nalo nigeria/en. Accessed 19 September 2015.

FAO. 2007a. Assessment of freshwater fish seed resources for sustainable aquaculture. FAO Fisheries Technical Paper, 501, Rome. 40pp.

FAO. 2007b. Food and Agriculture Organisation of the United Nations: for a world without hunger. Capture production 1950-2005. FISHSTAT Plus - Universal software for fishery statistical time series. FAO Fisheries and Aquaculture Department. Rome. 5pp.

FAO. 2010. Food and Agriculture Organisation of the United Nations Total fish consumption per capita $(\mathrm{kg})$ and fish contribution to total animal protein (\%), GLOBEFISH, www.globefish.org/ . Accessed 23 September 2015.

FAO Statistical Yearbook. 2013a. World food and agriculture. Rome, $307 \mathrm{pp}$.

FAO. 2013b. FAO Fisheries and Aquaculture Department. Global Aquaculture Production Statistics for the Year 2011. Aquaculture: the Blue Biotechnology of the Future. Thailand. 29pp.

FAO. 2014. Food and Agriculture Organisation of the United Nations. The State of World Fisheries and Aquaculture: Opportunities and Challenges. Rome. 3p.

FAO. 2016. Food and Agriculture Organisation of the United Nations. The State of World Fisheries and Aquaculture: Contributing to food security and nutrition for all. Rome. 200pp.

Financial Express. 2012. Nigerian envoy calls on president. Friday July 13 issue. vol 20, No. 220, Dhaka. Accessed 20 April 2016.

Finegold, C. 2006. The importance of fisheries and aquaculture to development. FAO Fisheries Technical Paper. Rome. 201p.

FRSS. 2013. Fisheries Resources Survey System, Fisheries Statistical Yearbook of Bangladesh. Department of Fisheries, Bangladesh. Vol. (30): 52p.

FRSS. 2014. Fisheries Resources Survey System (FRSS) Fisheries Statistical Yearbook of Bangladesh., Department of Fisheries, Bangladesh, vol. (31): 43p.

FRSS. 2015. Fisheries Resources Survey System (FRSS) Fisheries Statistical Yearbook of Bangladesh. Department of Fisheries, Bangladesh, vol. (32): 57p.
Gabriel, U.U., Akinrotimi, O.A., Bekibele, D.O., Onunkwo, D.N. and Anyanwu, P.N. 2007. Locally produced fish feed: potentials for aquaculture development in sub-Saharan Africa. African Journal of Agricultural Research, 2(7): 287295.

GFRAS. 2016. Global Forum for Rural Advisory Services (2016). Status of agricultural extension and rural advisory services worldwide. www.g-fras.org.en/word-wide-extension study/asia/southern asia. Accessed 6 April 2016.

Ghose, B. 2014. Fisheries and aquaculture in Bangladesh. Challenges and opportunities. Annual Aquatic Resources, 1 (1): 1001.

Haque, M.M., Alam, M.R., Alam, M.M., Basak, B., Sumi, K.R., Belton, B. and Jahan, K.M., 2015. Integrated Floating Cage Aquageoponics System (IFCAS): An innovation in fish and vegetable production for shaded ponds in Bangladesh. Aquaculture Reports, (2):1-9.

ILO. 2015. Migrant and Child Labour in Thailand's Shrimp and Other Seafood Supply Chains: Labour Conditions and the Decision to Study or Work. The Asia Foundation and International Labour Organization. 157pp

Islam, R. 2006. Bureaucracy and administrative development in Bangladesh and Nigeria: A comparative analysis. International Journal of Public Administration, 28 (1112):1009-1030.

Ita, E.O. 1989. Principles and practices of integrated commercial fish farming in Nigeria. National Institute for Freshwater Fisheries Research, New Bussa, Nigeria. Technical Report Series, No. 19, 31p.

Ita, E.O. 1993. Inland fishery resources of Nigeria. CIFA Occasional Paper, No. 20. Rome, FAO, 120p.

Jamabo, N.A. and Hart, A.I. 2015. Overview of fish farming in Nigeria: prospects and challenges, the Rivers state experience. World Aquaculture Conference, Adelaide power point presentation.

Latifa, G., Chakraborty, S. C., Begum, M., Farid, F. B. and Nahid, M. N. 2014. Comparative study of quality-analysis of three different Bangladeshi smoke-dried lean fishes using salt and turmeric stored at refrigeration temperature $\left(4^{\circ} \mathrm{c}\right)$. American Journal of Food Science and Technology, 2(6): 209-215.

Liu, J., Hull, V., Batistella, M., deFries, R., Dietz, T., Fu, F. and Hertel, T.W. 2013. Framing sustainability in a telecouped world. Ecology and Society. 18(2): 26.

Lola, G.K. 2009. Globalisation and poverty: comparative analysis of Bangladesh and Nigeria. In: proceedings of American Society of Business and Behavioral Sciences (ASBSS), Annual conference: Las Vegas, 16: 1, 13pp.

Mayer, J. 2000. Globalization, technology transfer and skill accumulation in low-income countries. Paper presented at United Nations Conference on Trade and Development, Geneva. 36pp.

Mayer, J. 2013. Towards more balanced growth strategies in developing countries: issues related to market size, trade balances and purchasing power. United Nations Conference on Trade and Development (UNDP), No. 214.http:// www.unctad.org. Accessed 25 June 2016.

Miller, J., Atanda, T., Asala, G., and Chen, W.H. 2006. Integrated irrigation-aquaculture opportunities in Nigeria: the Special Programme for Food Security and rice-fish farming in Nigeria. In: M. Halwart \& A.A. van Dam. (Eds). Integrated irrigation and aquaculture in West Africa: concepts, practices and potential, pp. 117-124. FAO, Rome. 181pp.

Mirzoyan, N., Tal, Y., and Gross, A. 2010. Anaerobic digestion of sludge from intensive recirculatory aquaculture systems. Review in Aquaculture, 1-6pp.

NBSN. 2015. National Bureau of Statistics Nigeria. Nigeria GDP from Agriculture @2015 TRADING ECONOMICS, www.tradingeconomics.com/nigeriagdp-7from-agriculture. Accessed 21 October 2015.

NDHS. 2013. Nigeria Demographic and Health Survey: Key findings. https: dhsprogram.com/pubs/pdf/SR 213. Accessed 20 June 2016.

Nwafili, N. and Tianxiang, C. 2007. Capture Fisheries and Aquaculture in Nigeria: A comparative analysis in issues in 
African rural development. Journal of Fisheries Management and Ecology, 8: 198-214

OECD. 2010. Organization for Economic Cooperation and Development. The development dimension of trade and environment: case studies on environmental requirements and market access. www.oecd.org/pcd/25497999.pdf. Accessed 25 June 2016.

Rahman, M. K. and Akhter, J. N. 2015. Ecology and Management of Inland Water and Fishery Resources of Bangladesh $\left(1^{\text {si }}\right.$ ed.), 38/2ka. Dhaka-1100. 440pp.

Sarker, A.K.M. R. A. 2009. Development of Cage-based Tilapia Farming in Dakatia River in Chandpur, Bangladesh: Study on Socio-economic and Technical Perspectives. Unpublished MSc Thesis, University of Stirling, UK. 85pp.

SARNISSA. 2013. Report Summary, Final Report Summary SARNISSA (Sustainable Aquaculture Research Networks in Sub Saharan Africa). http://cordis.europa.eu/result/rcn/ 56048_en.html. Accessed 23 December 2015.

Shimang, G. N. 2005. Fisheries Development in Nigeria, Problems and Prospects. A presentation by the Federal Director of
Fisheries in the Federal Ministry of Agriculture and Rural Development on Homestead Fish Farming Training for Serving and Retiring Public Servants in the Federal Ministry of Agriculture and Rural Development, FCT, Abuja, p 43-45.

Sikoki, F. D. 2013. Fishes in Nigerian Waters: No Place to Hide. An Inaugural Lecture Series, No. 100, delivered at the University of Port Harcourt, Nigeria.

The Fishsite. 2014. Nigeria Begins Import Quota Policy for FishNews. www.the fishsite.com/fisheries/23029/. Accessed on 6 March 2015.

The Nigerian Foods, 2016. www.AllNigerianFoods.com. Accessed 12 February 2016.

Worldometers. 2012. World Population Prospects: The 2012 Revision. www.worldometers.info. Accessed 26 August, 2015. 